Dobrawa Lisak-Gębala

Instytut Filologii Polskiej, Uniwersytet Wrocławski

\title{
Eseistyczna chopinologia Piotra Wierzbickiego
}

Zagadnienia związane ze sztuką należą do stałego repertuaru tematycznego eseistyki [zob. Tomkowski 2017: LXXV-LXXVIII]. Choć większą popularnością cieszy się problematyka malarska, to wśród pism z tego kręgu nie brak także tekstów skoncentrowanych na muzyce. Jeśli zaś weźmiemy pod uwagę autorów polskich, ewidentny stanie się - niezbyt zaskakujący - fakt: eseiści ci niezwykle często interesowali się kompozytorem uznawanym za najwybitniejszy talent w dziejach muzyki naszego kraju - Fryderykiem Chopinem ${ }^{1}$. Stąd eseistyczna chopinologia stanowi problem badawczy zdecydowanie godny uwagi.

Na wyróżnienie we wspomnianej grupie tekstów z pewnością zasługują książki monograficzne Jarosława Iwaszkiewicza i Ryszarda Przybylskiego, autorów niebędących profesjonalistami w dziedzinie wiedzy o muzyce i czerpiących z tej okoliczności oczywiste profity, powiązane z typowo eseistyczną swobodą wieloperspektywicznego opracowywania tematu. W pierwszym przypadku [Iwaszkiewicz

1 Z dawniejszej twórczości uwzględnić warto eseje Stanisława Przybyszewskiego, Cezarego Jellenty, Juliana Kadena-Bandrowskiego, Adolfa Nowaczyńskiego, Kazimierza Wierzyńskiego [zob. Pikulska 2008]. 
2010] najistotniejsza staje się biografia duchowa mistrza pianistyki, zaś programowo odczytywane dzieła - cytowane wielokrotnie w formie zapisów nutowych - okazują się skorelowane z określonymi momentami jego życiorysu; w drugim [Przybylski 1995] ważne są „myśli” Chopina wyczytywane w ramach unikalnego przedsięwzięcia „noologicznego” przede wszystkim z epistolografii muzyka wrażliwca. Uwzględnić warto w tym zestawieniu także książkę muzykologa Bohdana Pocieja [2012], która stanowi nacechowany literacko i subiektywnie esej wykraczający poza wąskie ramy specjalizacji tego badacza, skoncentrowany na tytułowej „polskości Chopina”.

W nakreślonym kontekście rozwijany przez dekady projekt eseistycznej chopinologii Piotra Wierzbickiego wyróżnia się nie tylko imponującym rozmiarem przedsięwzięcia². Oto bowiem eseista dyletant („[...] człowiek zza płota, zagapiony z zazdrosną czcią na szlachetne, dostojne postacie w niedostępnym ogrodzie muzyki, jak siedząc przy czarnych fortepianach czytają a vista z księgi hieroglifów rozsypanych na drabinie z pięciu kresek” [Wierzbicki 1993: 288-289]), mierząc się ze spuścizną romantycznego kompozytora, skupia się, i to w dużo większym stopniu niż jego koledzy po piórze, na samej muzyce - na tym, co uda mu się wyłowić podczas drobiazgowego porównywania rozmaitych wykonań, przefiltrowanych przez subiektywną percepcję, a także na tym, co sam, niezbyt udolnie przebierając palcami po klawiszach, zdoła odcyfrować z zapisów nutowych. Choć listy i inne świadectwa $z$ epoki także brane są przez Wierzbickiego pod uwagę, to tym, co przesądza o oryginalności jego projektu, okazuje się właśnie czynienie tematem eseju samej materii dźwiękowej, konkretnych realizacji pianistycznych bądź nawet pewnego „idealnego”

2 Projekt obejmuje: fragmenty tomu Życie z muzyka (1993), Chopin. Portret muzyczny (1999 - „dziełko życia” napisane po ponad 30 latach refleksji), Migotliwy ton. Esej o stylu Chopina (2010), Nieboski Chopin (2015 - tom zawierający zebrane wątki z trzech poprzednich książek, podane w innej konfiguracji i nieco przetworzone). W dorobku pisarskim Piotra Wierzbickiego oprócz muzyki (której poświęcił też liczne felietony) istotne miejsce zajmują metafizyka i sprawy polityczne. O ile ten pierwszy obszar zazębia się z kwestiami muzycznymi, o tyle ten drugi okazuje się zupełnie oddzielony od refleksji nad światem dźwięków. 
wykonania danego utworu, które stanowi indywidualną projekcję utkaną z życzeń doświadczonego melomana. Rasowy eseista, jak przekonywal György Lukács, konfrontując się z takimi właśnie tematami-,,odskoczniami”, przemycić umie poważne pytania filozoficzne i próbne odpowiedzi na nie [Lukács 1994: 83, 85, 87, 91] 3. $^{3}$. $\mathrm{Z}$ tego powodu dbać winien nie tylko o piękną formę tekstu, lecz także o frapujący ladunek poznawczy. Tak też postępuje autor Migotliwego tonu: wychodzi od konkretnych przebiegów dźwiękowych, a następnie zapędza się nieraz w dziedziny od muzyki dość odległe, aż do kwestii metafizycznych, związanych przykładowo z dialektyką konieczności i przypadku w świecie stworzonym przez „Muzykalnego Pana Boga”. Jego oryginalny sposób rozwijania możliwości tego gatunku w odniesieniu do muzyki został doceniony w 2015 roku przez jury Nagrody Literackiej Gdynia, które uhonorowało Wierzbickiego nagrodą w kategorii eseistyka za tom Boski Bach.

Biorąc pod uwagę powyższe wstępne diagnozy, projekt literackiej chopinologii autora Muzykalnego kosmosu można potraktować jako punkt wyjścia do próby stworzenia modelu esejów, w których nader istotne okazują się odniesienia do dźwiękowego konkretu. Głównymi problemami badawczymi opracowywanymi w niniejszym artykule staną się więc kwestie następujące: $z$ jednej strony - jakie zyski poznawcze i artystyczne w kontekście pisania o muzyce Chopina dał Wierzbickiemu wybór specyficznej formy eseju (jak gatunek ten pozwolił wysnuć i rozpisać w atrakcyjnych konstelacjach rozmaite znaczenia wyrosłe z prywatnych przeżyć melomana); z drugiej strony - czy sama forma eseju w tym wydaniu okazuje się narzędziem pozwalającym przybliżyć się do kompozycji Chopina, czy jest wzorem tekstu „muzycznego”, przepojonego żywiołem dźwięków i z tego właśnie względu odróżnialnego od innych realizacji gatunku. grafii [Lisak-Gębala 2016: 340] sugerowałam, że warto stworzyć intermedialną mapę współczesnych polskich realizacji tej formy pisania w kontekście tematu sztuki. Niniejszy artykuł łączy się jako postergon z poprzednim przedsięwzięciem, zgłębiając przypadek „odskoczni” muzycznych. 
„Esej ma swoje prawa” - deklaruje Wierzbicki w autotematycznym wstępie do tomu Chopin. Portret muzyczny [Wierzbicki 1999: 6]. Profity, ale też pewne zobowiązania, wynikające z wyboru formy eseju montaigne'owskiego ${ }^{4}$, można łatwo spostrzec podczas lektury prozy tego autora. Ewidentna staje się przykładowo swoista renesansowość podejścia Wierzbickiego - swobodnie łączy on rozmaite dziedziny, m.in. sztukę i naukę [por. Adorno 1990: 84]; ponadto pisząc erudycyjnie, niejednokrotnie zwraca się także ku codziennemu doświadczeniu. Mamy więc do czynienia z literatem, muzykofilem koneserem o zacięciu badawczym i filozofem w jednej osobie, który nawet śpiew ptaków potrafi opisywać jako koncertowe frazy [Wierzbicki 2010b: 27-28, 75-76, 144-145]. Znamiennym aspektem tego podejścia jest przekonanie o jedności psychosomatycznej człowieka, przypominające słowa Montaigne’a o „małżeńskiej przyjaźni” duszy i ciała [de Montaigne 2004: 837]. Wierzbicki pisze wprost: „W Etiudzie Ges-dur op. 25 utrwalono chwilę ludzkiej ciało-duszy" [Wierzbicki 1993: 142], a także przekonuje: „Muzyki słucha się duszą poprzez zmysł słuchu, ale także poprzez ręce, nogi, brzuch, serce, głowę, oczy, skórę, stawy" [Wierzbicki 1993: 26-27] (teza ta znajduje odzwierciedlenie w opisach tworzonych przez autora Życia z muzyka, co zauważył Andrzej Chłopecki, nazywając go „odbiorcą niemalże fizjologicznym, biologicznym” oraz „wirtuozem styszenia” [Smolka, Wierzbicki, Chłopecki, Kurkiewicz 2010: 138-139]). W dalszym ciągu cytowanego wcześniej eseju ujawnia się predylekcja Wierzbickiego do przemycania refleksji filozoficznych - okazuje się, że ludzka dusza słucha też w różnych kompozycjach własnej śmierci, bo muzyka według eseisty jest w sposób konieczny i przedwieczny uwikłana w czas (tę refleksję przekazał też w aforyzmie zamieszczonym w Jak Pan Bóg stworzył czas: „Rozłożył akord” [Wierzbicki

Esejoznawcy zgodnie uznają Próby Michela de Montaigne’a za paradygmatyczny przypadek eseju. Wskazują też na tradycję modernistycznych esejów programowych stworzonych przez admiratorów spuścizny ojca gatunku (Waltera Patera, Virginię Woolf, Györgya Lukácsa, Theodora W. Adorna i Maxa Bensego) [zob. Sendyka 2006]. Także współcześni amerykańscy obrońcy czystości elitarnie rozumianego eseju, tacy jak Phillip Lopate czy G. Douglas Atkins, wskazują na aktualność wzorca montaigne’owskiego. 
2002: 3017]). „Gęsia skórka” - owo „kryterium somatyczne” [Stefańczyk 2017: 111] - podobnie jak „szpila podnieceniowo-nerwowa” [Wierzbicki 1993: 143] przekonuje eseistę o wartości danej formy muzycznej. Swoją hierarchię ujmuje on następująco:

Muzyka, w której słyszę poruszenia własnej duszy, muzyka w której słyszę dźwięki, muzyka, w której słyszę klawiaturę (czy też jakieś baranie struny, blachy albo piszczałki) - oto trzy stopnie muzycznej duchowości na skali „o - nieskończoność”. [Wierzbicki 1993: 152]

Nie poprzestając na stwierdzeniu, że prywatne doświadczenie okazuje się w tej eseistyce probierzem wartości konkretnych dzieł i konkretnych wykonań, można śmiało powiedzieć, że ,ja” eksponujące swoją indywidualność i niezależność, nawet maskowane retorycznymi formami trzecioosobowymi lub formą pluralis, staje się niekwestionowanym centrum tekstu („Dobieram się do wczepionego w muzykę samego siebie. [...] aby dobrać się do muzyki” [Wierzbicki 1993: 5]).

To zresztą ,ja” specyficzne, zgodnie z tradycją kreowane na dyletanta (w sensie pozytywnym), któremu - także gdy się zapożycza u autorytetów - wolno pisać bez przypisów czy przyczynków i występować zdecydowanie swobodniej niż reprezentantom którejkolwiek okrzepłej specjalizacji, i który może nawet podjąć śmiałą „próbę wydarcia Chopinowi rąbka jego wielkiej tajemnicy” [Wierzbicki 2010a: 6]. Wierzbicki podsumowuje tę kreację w lakonicznym autoportrecie: „[...] autor co rusz puszcza się na mniej pewne wody spostrzeżeń i przypuszczeń własnych”, poruszać ma się ponadto „wąską ścieżką między przepaściami i mieliznami metafory a stromiznami muzycznej terminologii" [Wierzbicki 1999: 7]. Ów styl amatora łączy subiektywizm literackości przesyconej prywatnym doświadczeniem, swobodne filozofowanie, krytykę muzyczną i naukowość, jest „beznamiętno-namiętny, gorący w środku, chłodny z wierzchu" [Wierzbicki 1993: 5] - mówiąc słowami Chłopeckiego: łączy ucho, rozum i uniesienie [Smolka i in. 2010: 139]. 
Niejednokrotnie korzysta Wierzbicki z procedur, zdawałoby się, typowo naukowych: stawia tezy i traktuje jako dowody fragmenty dzieł wyliczone w sążnistej enumeracji, szuka esencji pewnych zjawisk muzycznych i przymierza do nich zwięzłe formuły (takie jak chopinowska „migotliwość tonu” [Wierzbicki 2010a]), wypisuje od myślników 12 elementów Hummlowskich u Chopina, wyłowionych dzięki muzykologicznej analizie pojedynczych motywów, nawet pojedynczych pasaży lub ozdobnika [Wierzbicki 1999: 17], czy też drobiazgowo rozkłada na 13 cech styl chopinowskich wykonań Józefa Hoffmana [Wierzbicki 1993: 201-215]. Eseista celuje jednak także w śmiałych doświadczeniach myślowych, w których pojawiają się intrygujące chwyty literackie (np. prośba do wyimaginowanego „odgadywacza” o domyślenie się dalszych ciągów Chopinowskich fraz, ucięta dowodzeniem, że to niemożliwe, a nawet że Chopina nie da się cytować, gdyż wyrwane frazy są „ogołocone z sensu” [Wierzbicki 1993: 94-99]). Czasem i wspomniane eksperymenty są z pozoru ścisłe, jak porównywanie kompozycji, fragmentów parami lub opowiadanie losów Chopina przy pomocy chronologicznie ułożonych ekfraz jego dzieł [Wierzbicki 2010a: 33-39]. Innym razem okazują się jednak zupełnie ekstrawaganckie, jak pomysły, zmierzające ku „rozkosznej otchłani wariactwa”, na arcyoryginalne transkrypcje dzieł Chopina, np. Impromptu Fis-dur w wersji na chór mieszany, dwie harfy i trzy wiolonczele [Wierzbicki 1993: 161-172], bądź portret imaginacyjny ${ }^{5}$ kompozytora napisany w czasie teraźniejszym („I oto widzę, jak Chopin-przedrzeźniacz staje naprzeciw tysiąca chwil ciała, tysiąca chwil duszy, by je odtworzyć [...] słyszę, jak struny fortepianu pod palcami naśladowcy-magika odgrywają tysiąc strun ciała, tysiąc strun duszy" [Wierzbicki 1993: 147-148]). Pojawiają się tu także fantazje i dociekania z kręgu historii ewentualnej, przykładowo liczne dialogi tajemniczych dyskutantów przywoływanych w tekście, takie

5 Figurę tę skojarzyć można z tradycją eseistycznych portretów artystów wyrosłą z Imaginary Portraits Patera (1887) [por. Zawadzki 2001: 97-118 (rozdz. Portret jako gatunek wypowiedzi filozoficznej (od Patera do Micińskiego)); Lisak-Gębala 2016: 251-253]. Nie bez powodu książka Chopin Wierzbickiego nosi znamienny podtytul: Portret muzyczny. 
jak zmyślona salonowa riposta Chopina (jak gdyby już z zaświatów) na krytykę Sonaty h-moll przez Debussy'ego [Wierzbicki 2015: 32] czy pytanie „Co by się stało, gdyby Chopin skomponował Sonatę wiolonczelową pięć-dziesięć lat wcześniej, [...] gdyby cały Paryż czekał na tę nową muzykę, chciał za nią placić i ją grać?” [Wierzbicki 1993: 160]. To celebrowanie swobody dyletanta ma wielokrotnie nacechowanie polemiczne względem tradycyjnej recepcji i „dydaktycznych czytanek” wychwalających kompozytora narodowego. Eseista nie pisze „na kolanach”, bo „z klęczek widać akurat najgorzej” [Wierzbicki 1999: 6], lecz dostrzega Chopinowski humor i ironię, a także niechęć kompozytora do wszelkiego mędrkowania. Wierzbicki nieraz nie przebiera w słowach: „Durniami i dyletantami byli romantyczni i neoromantyczni interpretatorzy, co to dopatrywali się elfów i wróżek" [Wierzbicki 1999: 113]. Wytyka innym przeoczenia: muzykologom - że przegapili to, iż Chopin był modnisiem i koniunkturalistą [Wierzbicki 1993: 146]; Ingardenowi - że widzi kompozycje tylko jako byty abstrakcyjne $\mathrm{i}$ „nie patrzy dziełom muzycznym w twarze [...]” [Wierzbicki 1993: 176]. Owo votum separatum odnawia recepcję, wpisując się tym samym w projekt „idealnego” eseju [zob. Adorno 1990: 97]. Przywołane polemiki mają często wymiar nie tylko antynaukowy, ale też antyabstrakcyjny, zwrócony ku codzienności, przyziemnym uwarunkowaniom sztuki, ku prywatnemu doświadczeniu i konkretowi zmysłowemu.

To cechy zdecydowanie montaigne'owskie, wsparte często pokrewnym względem pism renesansowego humanisty sceptycyzmem (np. w diagnozie dotyczącej dzieł Chopina: „Ta muzyka jest zjawiskiem zbyt złożonym, a także zbyt pełnym sprzeczności, by się można było do niej, do końca, do samego środka jej istoty dobrać jakimiś cudownymi formułami, a już pod żadnym pozorem nie wchodzi w grę coś takiego, by to mogła być jakaś jedna formuła" [Wierzbicki 1999: 100]) oraz retoryką skromnościową (np. „[... podejmijmy próbę wydarcia Chopinowi rąbka jego wielkiej tajemnicy i, mając za drogowskaz nasz zwykły, pospolity słuch, ogarnijmy ekstrawagancje, unikalności i unikalnostki poszczególnych Chopinowskich dzieł, by je zmierzyć ze sobą i, jak Bóg da, 
zestrzelić w jeden wszechogarniający ton" [Wierzbicki 2010a: 6]). Eseje Wierzbickiego, często utrzymane $\mathrm{w}$ tonie hipotetycznym [por. Bieńkowska 1976: 103], naszpikowane są pytaniami - niektóre z nich, by powtórzyć za Montaigne’em, „miarkują śmiałość [...] twierdzeń”, inne mają charakter czysto retoryczny i pozostawiają rozważaną kwestię bez zwieńczenia (przykładowo trzy wykluczające się opcje w pytaniu dotyczącym Etiudy c-moll op. 25 nr 12: „Czyż przygodnie, mimochodem nie przemawia tu przez parę minut nastrój niezgłębionych otchłani Kosmosu albo sam chaos, sprawca wszystkich rzeczy, albo niedostępna kiedy indziej naszym uszom harmonia sfer?" [Wierzbicki 2010a: 88]). Nawet wypracowana formula Chopinowskiego "migotliwego tonu” tak naprawdę niewiele wyjaśnia (co wpisuje się w ideał niekonkluzywności i otwartości poznawczej eseju [Lukács 1994: 92]). Jako wielowykładalna, poetycka enigma może jedynie pomieścić sprzeczności stylu mistrza, a także przy okazji przemycić refleksje stricte filozoficzne:

Migotliwość jest żywiołem tej muzyki. Ale migotliwość jest też żywiołem ludzkiej natury. [...] Trasy ludzkiej duszy są, o ile nikt nie patrzy, kręte, nieoznakowane, wolno wątpić, czy do końca wytyczone. [...] Tak migotliwość mowy dźwięków wchodzi w rezonans z rozbrykaniem tęsknot, lęków, żalów, zgryzot i zachcianek. Tak ludzka dusza odnajduje w stylu Chopina naturę własną. [Wierzbicki 2010a: 96]

Amatorska antropologia muzyki staje się antropologią sensu largo (nauką o człowieku), nawet więcej - koncepcją filozoficzną ujmującą naturę wszechbytu: „A czyż świat cały w jego bezkresnym ogromie $[\ldots]$ coś innego stanowi, jak imperium sprzecznych prądów?” [Wierzbicki 2010a: 96]. Cytowany tekst Wierzbickiego, przechodząc od ekfrazy Sonaty b-moll do natury wszechrzeczy, pokonuje drogę eseju wskazaną dobitnie przez Lukácsa: „niewidocznymi poniekąd, po części, powiadają, mniemam, i tym podobne»" [de Montaigne 2004: 776]. 
literami" dopisuje do tematu-pretekstu próbne odpowiedzi na najistotniejsze pytania filozoficzne [Lukács 1994: 91].

W eseistyce muzycznej Wierzbickiego odnajdziemy więcej fragmentów wymykających się ku kwestiom uniwersalnym, o czym przekonuje powracająca figura „Muzykalnego Pana Boga”. Wielokrotnie przewijają się tematy z kręgu filozofii kultury i sztuki, takie jak tragizm, piękno i brzydota, relacja geniusza do momentu dziejowego [np. Wierzbicki 1993: 113-114] czy folkloru bądź gustu powszechnego do kultury artystycznej [Wierzbicki 1993: 134-135]. Eseistę nurtują też zmienne koleje recepcji - dlań niekwestionowanych - mistrzów oraz zagadnienie tradycji i awangardowości. Zahaczając zaś o powszechny w eseistyce „banal filozoficzny” [zob. Głowala 2014: 118], autor Migotliwego tonu odnosi się w kontekście muzyki Chopina do przemijania, konieczności i przypadku czy kulturowych stereotypów kobiecości, męskości i duchowego dziecięctwa, oczywiście opracowując je w niesztampowy sposób [np. Wierzbicki 1999: 91-100].

Eseistyczna chopinologia Wierzbickiego, mimo autotematycznych deklaracji, nie dotyczy zatem tylko muzyki romantycznego artysty czy też jego sylwetki twórczej. Okazuje się natomiast oryginalnym próbowaniem się myślowym eseisty z bogatą kolekcją zagadnień, w ramach którego to właśnie konfrontacja z muzyką pozwala przemycać refleksje na temat innych sfer rzeczywistości, co idealnie wpisuje się w ekstradyscyplinarny wzorzec gatunku znany z tradycji literackiej, jednocześnie zgodny z elitarnymi postulatami filozofów eseju. Warto jednak zająć się i drugim zadeklarowanym na wstępie problemem, który z kolei wskazać mógłby na swoistość i oryginalność rozwiązań artystycznych i poznawczych Wierzbickiego, a zarazem pozwoliłby zmierzyć się z kwestią domniemanej swoistości wzorca eseju dotyczącego muzyki. Czy swobodnie potraktowany temat muzyki sprawia, że omawiane eseje stają się „muzyczne”?

Co ciekawe, mgliście sygnalizowaną „muzyczność” eseju i to w ramach rozważań nad ogólnym wzorcem gatunku w kontekście dowolnego tematu - wskazywano już niejednokrotnie; tezy te pomóc mogą zatem wytyczyć pewne podstawowe wymiary interesującego mnie zjawiska. Nieskrępowany, asocjacyjny tok eseju 
ujmowano często przy pomocy metafor muzycznych [Sendyka 2006: 292-293]. Ponadto Aldous Huxley postulowal, by przejścia między różnorakimi perspektywami w eseju były płynne i bezszwowe niczym modulacja z tonacji do tonacji [Huxley 1960: 90]. To wszystko w imię „logiki, która chce śpiewać” [D’Agata 2012: 170; przeł. - D.L.G.] czy „logiki muzycznej”:

ścisłej a przecież bezpojęciowej sztuki przechodzenia, aby mówiącej mowie przyswoić coś, na czym poniosła uszczerbek pod panowaniem logiki dyskursywnej, która przecież nie daje się przeskoczyć, ale którą można przechytrzyć tylko w jej własnych formach siłą wnikającego w nie subiektywnego wyrazu. [Adorno 1990: 98]

W ten sposób swoboda poznawcza splata się w eseju ze swobodą artystyczną (przede wszystkim w zakresie niepodległej schematom kompozycji tekstu), otwiera się w nim przestrzeń do wyrażania indywidualnej prawdy, a piszący może nawet wzbić się ku „nadnaukowości” [Adorno 1990: 98].

Wierzbicki sam deklaruje „muzyczność”, a nie jedynie „literackość” swego portretu Chopina, przy czym ma na myśli zarówno kompozycję, jak i prozodię tekstu. Wyznaje: „Autor nie będzie udawał, że ambicją jego nie było nadać tej książce pewien specyficzny rytm [...]" [Wierzbicki 1999: 6]. Także we wstępie do zbioru felietonów muzycznych przekonywał o potrzebie przyległości stylu i formy pisania do obranego tematu: „Trzeba [...] sprawić, by rzecz o muzyce sama stała się muzyczna choć po trochu, miała melodię własną, własny rytm” [Wierzbicki 2010b: 5]. Zdaniem Romana Kurkiewicza eseista faktycznie potrafi „zbudować zdanie, które brzmi, które trwa [...]” [Smolka i in. 2010: 141]. Obecność tych właściwości kompozycyjnych i prozodycznych jest w pewnym sensie uchwytna uchem7 ${ }^{7}$ nie sposób zaś dowieść jej w sposób

7 W tym zakresie pisarstwo Wierzbickiego przypomina „umuzyczniony” felieton Stefana Kisielewskiego [zob. Hawryszków 2011: 151-155]. Co ciekawe, Andrzej Chłopecki właśnie z Kisielewskim zestawił Wierzbickiego, mając jednak raczej na myśli jednoczesne zaangażowanie obu twórców w krytykę muzyczną i publicystykę polityczną [Smolka i in. 2010: 138]. 
stricte naukowy (to zatem „muzyczność” traktowana metaforycznie [por. Hejmej 2002]). Są to jednak właściwości przyciągające uwagę do samej sfery dźwiękowej tekstu i wykraczające poza zakładany w modelu gatunku, obowiązkowy wręcz polor stylistyczny.

Przepojona subiektywnym wyrazem eseistyczna chopinologia Wierzbickiego wpasowuje się miejscami w model sound writing (pisarstwa dźwiękowego), w którym „dźwięk jest nie (tylko) obiektem analizy, ale [także - D.L.G.] wibracją, która przepaja słowo swą własną materialnością, by stworzyć trzecią rzecz. Jako takie sound writing jest wymiarem zapisu słuchania" [Kapchan 2017: 11; przeł. - D.L.G.]. W tym modelu przełamywana jest dualistyczna opozycja słuchającego podmiotu i słuchanego obiektu, zaś w wielowymiarowej sferze pomiędzy tymi biegunami sytuuje się właśnie pisarstwo dźwiękowe, w którym splatają się afektywne elementy pochodne od

pisarza słuchającego dźwięku i tłumaczącego go poprzez cielesne doświadczenie, ciała tłumaczącego spotkanie pomiędzy słowem i dźwiękiem, dźwięku tłumaczącego i przekształcającego zarówno słowo, jak i autora. [Kapchan 2017: 12; przel. - D.L.G.]

Notabene teoria ta znakomicie współgra z deklaracją autora Nieboskiego Chopina, w której odnosi się on do słuchania muzyki całym ciałem [Wierzbicki 1993: 26-27].

Dążąc do wyłowienia konkretnych elementów quasi-muzycznych w pisarstwie Wierzbickiego, zwrócić należy uwagę na potoczysty styl - w jego esejach wartki strumień lączy niejednorodne elementy (muzykologiczne, krytyczne, literackie, ekspresyjne, filozoficzne...) w artystycznie spójną całość. Czynnikiem dyscyplinującym są liczne powtórzenia, np. paralelizmy składniowe czy bardzo charakterystyczne refreny rozsiane po tomie Migotliwy ton, każdorazowo rozpoczynające się od słów „Styl Chopina to [...]” [Wierzbicki 2010a]. Narracja ma zmienne tempo - raz przyspiesza, raz zwalnia; niektóre zgęszczone passusy operują seriami zdawkowych równoważników zdań bądź enumeracją, inne zaś zawierają rozwlekłe, detaliczne opisy. Ów swoiście „muzyczny”, podług deklaracji autora, styl stanowić może zabieg mimetyczny względem 
migotliwości muzyki Chopina - raz wartkiej, raz melancholijnej, z jej tendencją do rubata i traktowania tempa ad libitum.

Czy jednak „muzycznie” pojęty esej okazuje się wyjątkowo zdatny do konfrontowania się z fenomenem, który stawia opór wysłowieniu? Topos nieopisywalności muzyki ma wszak długą tradycję [zob. Hejmej 2002: 73; Barska 2008: 80; Górny 2017: 13-35]. Fragmentów mierzących się z muzycznym konkretem jest w eseistyce Wierzbickiego wyjątkowo dużo. Mimo licznych zastrzeżeń, którymi obwarowane jest używanie terminu „ekfraza” w odniesieniu do opisu dzieł muzycznych, będę stosować to określenie w kontekście deskrypcji autorstwa Wierzbickiego. Przyjmuję podobnie jak Paulina Kierzek-Trzeciak [2010: 57-59] - wyrosłe $\mathrm{z}$ tradycji starożytnej rozumienie ekfrazy jako figury retorycznej mającej dostarczyć iluzji bezpośredniego obcowania z opisywanym obiektem lub wydarzeniem (będzie nim np. wykonanie kompozycji, wtedy opis ustępuje często opowiadaniu, co pozwala uwzględnić czasowość muzyki).

Ekfrazy autora Migotliwego tonu są bardzo dopracowane pod względem stylistycznym. Jak przystało na eseistyczny wariant tej figury - dominuje w nich funkcja ekspresywna, gdyż subiektywnie opisywane dzieła muzyczne stają się „lustrem”, w którym przegląda się ,ja”, jednocześnie portretując siebie i swoje aktywności - nie tylko czysto zmysłowe, ale też poznawcze i emocjonalne [zob. Sendyka 2009: 58] $]^{8}$. Przyjęcie tej optyki pozwala potraktować taką wieloperspektywiczną ekfrazę w eseju jako realizację eklektycznego, „poetycko-interdyscyplinarnego" modelu opisu dzieła muzycznego podług schematu Andrzeja Hejmeja. Chodzi mianowicie o typ, który łączy artystycznie ujęty opis relacji słuchacza z muzykologicznym opisem dzieła [Hejmej 2002: 73-86]. Tego rodzaju ekfrazy w tomach Wierzbickiego oczywiście nie są prostym, „wiernym” przekładem Chopinowskich kompozycji, dają jednak dostęp zarazem do subiektywnych doznań „wirtuoza słyszenia” oraz do elementów obiektywnej wiedzy fachowej. Eseista wytrawnie posługuje się terminologią muzykologiczną, jednocześnie nie pozwalając tekstowi ugrzęznąć w nużących dłużyznach 
i beznamiętnym stylu. Metafory bywają wprowadzane w opisach metodycznie, jako rozwinięcia pewnych konceptów funkcjonujących w muzykologii i w mówieniu o pianistyce. Ekfrazy często stają się dowodami stawianych tez, innym razem, jako forma pisania nie wprost, oferują sposobność do takich tez przemycania, włączone są bowiem w „logikę muzyczną” eseistycznego przebiegu.

Warto oczywiście dodać, iż fundamentalna różnica między ekfrazą dzieła malarskiego a ekfrazą dzieła muzycznego polega na tym, że podczas gdy to pierwsze istnieje jako niezależny, statyczny obiekt, to drugie wymaga wykonawcy, który dokona konkretyzacji utworu. Słuchacz zdany jest na subiektywizm własnej percepcji, w czym przecież nie różni się od miłośnika malarstwa, ale dodatkowo okazuje się zależny także od muzyka prezentującego dzieło. Wierzbicki w odniesieniu do kompozycji Chopina ma intrygującą teorię, dowodzi bowiem, że muzyka polskiego romantyka rozumiana jedynie jako szkic kompozytorski zawarty w nutach jest bardziej zależna od wykonawcy niż inne przykłady muzyczne, zatem gdy pianista nie sprosta zadaniu wprawienia zaplanowanych dźwięków w ruch, także „Chopin znika” [Wierzbicki 1993: 178]. W kontekście tej tezy zrozumiałe staje się (jeśli pominiemy uwarunkowania techniczne związane z odmiennymi czasami), dlaczego Wierzbicki do tomu Nieboski Chopin dołączył płytę z podziwianymi przez niego wykonaniami (podobnie uczynił w przypadku tomu Boski Bach), podczas gdy u Iwaszkiewicza pojawiają się same nuty [Iwaszkiewicz 2010], sugerujące poniekąd, że muzyka Chopina istnieje w nich jak gdyby obiektywnie.

Pożądana przez Wierzbickiego ruchliwość wykonań ukochanych dzieł połączona z zaangażowaniem eseisty przekłada się na jego sposób pisania o muzyce - to pisanie dynamiczne, na wskroś subiektywne (wszak nieraz przefiltrowane aż przez dwie podmiotowości: wykonawcy i literata-słuchacza). Prawie zawsze utrzymane jest ono w formie praesens, co podkreśla bezpośredniość kontaktu $\mathrm{z}$ danym utworem, nawet gdy Wierzbicki nie opisuje konkretnego cudzego wykonania, a jedynie realizację wyobrażoną, prywatny ideał wykonawczy. Króluje tu tryb synestezyjny (dowodem jest np. wyrażenie „deszczowozielona powłoka Sonaty” [Wierzbicki 1993: 163]), co nie dziwi w świetle wspomnianej wiary eseisty-melomana 
w jedność psychosomatyczną słuchaczy. Dodatkowo Wierzbicki deklaruje, iż z Chopinem - jako kompozytorem, który od lat młodości miał kształtować jego duszę - ma wyjątkową więź: „więź realną namacalną, cielesną" [Wierzbicki 1993: 23-24]. Oczywiście jako bywalec konkursu chopinowskiego, innych festiwali i koncertów, namiętny słuchacz radia i nagrań płytowych (głównie tych dawnych, pełnych szumów i niedoskonałości [Wierzbicki 2010b: 45]) także o konkretnych wykonaniach pisze bardzo chętnie. W jego galerii sław prym wiodą pianiści starej daty. Sondując niuanse różnicujące odmienne style wykonawcze tytanów klawiatury, Wierzbicki także operuje wspomnianymi metaforami synestezyjnymi, polisensorycznymi, co zresztą postrzegać można jako daleko idące rozszerzenie tendencji zaznaczającej się już w samym wokabularzu muzykologicznym, w którym wszak funkcjonują takie określenia, jak kolorystyka czy ciemna bądź jasna barwa dźwięku. Eseista przykładowo porównuje typ „dźwięku soczystego, matowego, grubego” (np. Backhausa) z typem dźwięku „cienkiego, suchego, ostrego" (np. Horowitza [Wierzbicki 1993: 204]); „dźwięk szpileczkowy" (znów Horowitza) z dźwiękiem o kształcie kulki (u Hoffmana [Wierzbicki 1993: 205]). Podziwianym kreacjom chopinowskim poświęca obszerne, zmysłowe akapity pełne przenośni, w tym częstych animizacji i personifikacji. W finale takich bogatych w szczegóły wywodów zdarzają się i podsumowujące formuły-skróty - jak ta właściwie już katachretyczna puenta opisu wykonania Walca Des-dur op. $64 \mathrm{nr} 1$ przez Hofmanna: „[... ] ten kołowrotek ma konary, gałęzie, rośnie, wije się, oddycha" [Wierzbicki 1993: 214].

W nielicznych przypadkach eseistycznych ekfraz podejmowane są nawet próby maksymalnego zbliżenia się poprzez słowo, a konkretnie onomatopeje, ku muzyce, aby sam tekst nabrał walorów dźwiękonaśladowczych (Wierzbicki wspomina „zdrowe, polonezowe «tam - taratam - tam - tam»" w Polonezie-Fantazji [Wierzbicki 2010a: 83] czy „papam-pam” w obojętnej końcówce Mazurka cis-moll [Wierzbicki 2010a: 69]). W ten sposób złudzenie „nauszności” pojawia się zamiast złudzenia naoczności (enargeia), wymaganego w przypadku ekfrazy dzieła z kręgu sztuk wizualnych [zob. Markowski 1999]. Ta iluzja wynikać też może z próby 
naśladowania zmiennej, dynamicznej formy utworu, jak w ekfrazie szaleńczego, „najbardziej romantycznego spośród romantycznych dzieł Chopina”, Scherza b-moll, która zarazem precyzyjnie i metaforycznie rejestruje kolejne etapy kompozycji:

Pytanie natarczywe, gwałtowne, z nutką groźnej zapowiedzi. Głos zawieszony na ostatnim dźwięku zdania. Pauza: czekanie na efekt. Odpowiedź w pięciu trzaskających akordach. Gamkowy zawijas... Zwrot: z małych nutek wyskakuje ogromna kantylena, by wzlatywać, wzlatywać, wzlatywać. Jest rezolutna, przebojowa, bez kompleksów, wysnuwa z siebie - do oporu! - kolejne dalsze ciągi, by, osiągnąwszy kres, oddać głos paru wściekłym łomotom... Zwrot: powtórka wszystkiego od początku. Zwrot: senne akordy wokół czeredy równie sennych nutek... Zwrot: podrywa się jeszcze jedna kantylena, słodka, prosta jak piosenka... Zwrot: na kantylenę wpada rozszalały pasaż, grubieje, potężnieje, po czym gwałtownie się urywa... Zwrot: powtórka całego epizodu począwszy od sennych akordów, tym razem jednak akcja nie zostaje przerwana, lewa ręka zaczyna w basach wystukiwać gorączkowo oktawami rytmiczny motyw, wpasowuje się weń tamta słodka, prosta jak piosenka kantylena przemieniona teraz w gorączkową, opętańczą galopadę, akcja, pogoniona ledwo mieszczącymi się wtrąconymi gamkami, gwałtowanie przyspiesza i szczytuje w szarpaninie odpychających, ciemnych, ciężkich tonów... Zwrot: powrót do punktu wyjścia, cztery zawołania, cztery odpowiedzi, wielka kantylena i final, dziwnie pusty, za to wielce, ale to wielce hałaśliwy. [Wierzbicki 2010a: 30-31]

Zaznacza się tu dążenie do uzyskania przyległości opisu względem przebiegu utworu, choć oczywiście wysłuchanie scherza trwa dłużej niż lektura tego akapitu. Ramą tej sekwencji jest muzykologiczna precyzja, ale ekfraza nie byłaby tak sugestywna, gdyby nie dbałość autora o styl "muzyczny” - o odpowiednie tempo, interpunkcję, a nawet elementy instrumentacji głoskowej („senne akordy wokół czeredy równie sennych nutek”) oraz znaczące powtórzenia, które odpowiadać mają określonym momentom dzieła. Oddawać 
prywatne doświadczenie scherza ma także słownictwo nacechowane (np. zdrobnienia „gamka”, „nutki”) oraz subtelne metafory o funkcji heurystyczej, animizujące bądź personifikujące przebiegi dźwiękowe, nieuchronnie zatem przesuwające je ku czemuś im obcemu, ku wzlatującym ptakom lub dialogującym głosom. Wierzbicki nie podkłada jednak naiwnych treści programowych, pragnie znaleźć najlepszy słowny odpowiednik muzycznego „dziania się” migotliwej kompozycji.

Wśród werbalnych ekwiwalentów narracji muzycznej - nie tylko u Wierzbickiego - pojawiają się często określenia traktujące przebiegi dźwiękowe jako zdania, co oczywiście koresponduje z takimi określeniami muzykologicznymi, jak fraza i zdanie muzyczne. Autor Migotliwego tonu, korzystając z tej konwencji, wprowadza oryginalne rozwiązanie dotyczące interpunkcji muzycznej u Chopina. Dowodzi, że u tego kompozytora właściwie nigdy na końcu zdania muzycznego nie pojawia się kropka, zamiast niej występuje natomiast znak zapytania, wielokropek lub dwukropek, często mają się pojawiać także zdania wtrącone, jak gdyby wydzielone nawiasem [np. Wierzbicki 1993: 99, 2010a: 69, 94]. Ta tendencja w zacytowanej ekfrazie Scherza $b$-moll ujawniała się pod postacią sześciu wielokropków, które miały być odpowiednikami zawahań i pauz, a także pod postacią innych znaków, jak półpauzy wydzielające wtrącenie, wykrzyknik, liczne kropki i przecinki. To właśnie interpunkcja tworzy w cytowanej deskrypcji zwichrowany, jak gdyby chopinowski rytm. W efekcie przebiegi scherza zdają się funkcjonować jako jedna $\mathrm{z}$ warstw tego oryginalnego opisu, jako „wibracja, która przepaja słowo swą własną materialnością" - jak postulowała Deborah Kapchan [2017: 11], opisując model sound writing.

Jeśli traktować wspomniane „muzyczne” rozwiązania autora Migotliwego tonu jako ważny składnik modelowego eseju bezpośrednio odnoszącego się do konkretnych kompozycji, właśnie w tym eksperymentalnym aspekcie szukać można differentia specifica wyróżnionego typu. Przy czym pamiętać jednak trzeba, że nie jest to muzyczność dzieła literackiego ściśle rozumiana (naśladowanie formy, czyli muzyczność III [zob. Hejmej 2002]). Zmierzając ku podsumowaniu niniejszych rozważań, należy zaznaczyć, że do 
omawianego powyżej konceptu korespondencji muzyki Chopina i języka Wierzbicki powraca wielokrotnie, traktując ów temat $\mathrm{z}$ rezerwą. Temu słowno-muzycznemu - poniekąd autotematycznemu - wątkowi z kręgu translatoryki interartystycznej warto przyjrzeć się szczególowo.

W jednym z felietonów Wierzbicki zastanawia się nad tym, czy można znaleźć paralelę melodii zdań w listach (gdzie „nie ma zbędnych słów, zaś akcent pada zawsze na przedostatnie") z rytmem nokturnów, preludiów i Sonaty h-moll [Wierzbicki 2o1ob: 40-41], zaś w eseju Język szczegółowo i sceptycznie roztrząsa możliwe konsekwencje interpretacyjne słów samego Fryderyka, który w przedmowie do planowanego zbioru Metoda gry na fortepianie pisał o tym, że muzyka „wyraża myśli” [Wierzbicki 1999: 111-122]. Nieuchronnie rodzi się więc wątpliwość metodyczna: czy zatem interpretator tych kompozycji powinien pisać o myślach „wyczytanych” z dzieł? W odpowiedzi eseista sugeruje tylko, że w utworach Chopina-,,przedrzeźniacza” możemy rozpoznać nie dokładne „wypowiadane” kwestie, a jedynie pewne jak gdyby teatralne scenariusze wypowiedzi wraz z ich określoną aurą emocjonalną, które wprowadzane są przez postać „narratora” tej muzyki (jak wołanie, perswazja, westchnienie lub seria pytań i odpowiedzi, czy też „[m]amrotanie i szemranie, gwizdanie i podśpiewywanie, zwykła mowa i chrypienia, deklamacja, bełkot i szept” [Wierzbicki 1993: 147]). Jednak do idei teatru z figurą „opowiadacza” w kompozycjach Chopina Wierzbicki powraca wielokrotnie, traktując wybrane dzieła jako szkicowe, często parodystyczne ekwiwalenty narracji epickiej. Stąd wynika np. podkładanie pod muzykę fraz inicjalnych typu „Pewnego razu”, „Wyobraź sobie”, „Zaczęło się tak” [Wierzbicki 1993: 143" ${ }^{9}$, 2010a: 50 $0^{10}$, lecz opowieści te nie mają żadnego rozwinięcia. Choć więc Chopin w pewnym sensie faktycznie "gada" na fortepianie, to nie ma możliwości dokonania przekładu muzycznych fraz na słowa w stosunku jeden do jednego.

Tezę, że Chopin jedynie przedrzeźnia samą sytuację opowiadania, powoławszy w tym celu muzycznego narratora, którego 
jednak nie sposób zrozumieć, najdobitniej eksponuje Wierzbicki przy pomocy porównania do sceny z Czarodziejskiej góry Tomasza Manna, w której to „Osobistość Wielkiego Formatu” (czyli Peeperkorn) z zapałem peroruje do wtóru huczącego wodospadu, tak że słychać jedynie strzępy słów, a z całości można wyczytać tylko niewiele mówiącą ramę wypowiedzi, same pozy i uczucia [Mann 2008: 695]. To najwyraźniej koncept niezwykle istotny dla autora, gdyż w jego chopinologicznej eseistyce powraca aż trzykrotnie [Wierzbicki 1999: 118-119, 2010a: 143-144, 2015: 48-49]. Skoro tak, warto z tej literacko rozpisanej myśli przewodniej spróbować wysnuć gębszą interpretację. Może nie tylko Nokturn Des-dur, ale i cała muzyka Chopina byłyby dla eseisty jak asemantyczny, lecz przesycony burzą namiętności dźwięk wodospadu z urywkami słów? Z jednej strony można potraktować ten koncept jako autotematyczne wskazanie trudności, z jakimi mierzy się słuchacz Chopina, szczególnie ten, który chce muzykę opisać - zostają mu strzępy zdań oraz dźwięki i emocje, których przecież nie można bezpośrednio przełożyć na słowa. Trzeba więc zachodzić je od różnych stron, metaforyzować, eksperymentować ze stylem „muzycznym”, szukać adekwatnych chwytów literackich, nieuchronnie wprowadzając do opisu elementy już pozamuzyczne, „ożywiając” kompozycje, przemieniając ją w teatrzyk. Z drugiej strony Mannowska scena ma niewątpliwie charakter parodystyczny. Odnosząc się do niej, Małgorzata Łukasiewicz zapytała nawet zaczepnie: „Czy Mann przypadkiem nie zaprowadzil nas do opery, żeby pokazać, czym jest pierwszej klasy Gesamtkunstwerk, pod dyrekcją autokratycznego mistrza Wagnera?” [Łukasiewicz 2011: 138]. Do tego ładunku parodystycznego i ironicznego Wierzbicki świadomie się odwołuje - nie tylko krytykując tych interpretatorów, którzy naiwnie podkładali treści programowe pod asemantyczne Chopinowskie dzieła, ale też sceptycznie podchodząc do własnego przedsięwzięcia „stylobraniowego" [Wierzbicki 2010a: 92], do zamiaru opisywania muzyki idola, gdyż przemienić się on może łacno - jeśli autor za bardzo się zapędzi - w przeładowane Gesamtkunstwerk, obciążone nieuprawnionymi pozamuzycznymi analogiami. Płynąłby stąd wniosek następujący: gdy chce się łączyć słowo i muzykę, prymat należy oddać samej muzyce. 
Ów sceptycyzm w kontekście niezwykle ambitnego planu Wierzbickiego względem muzyki mistrza (,[...] wyrazić choćby w jakimś najmniejszym ułamku owo coś, tak oczywiste, gdy jej słuchamy, i uczynić to wszystko w języku własnym [...]" [Wierzbicki 1999: 7]) okazuje się też na wskroś eseistyczny. Wkraczając na ścieżkę radosnego ryzyka nadinterpretacji - w przypadku eseistycznej chopinologii Wierzbickiego powiązanego nie tylko ze śmiałymi interpretacjami dyletanta, ale też z eksperymentalnie wprowadzanym "stylem muzycznym” - eseista korzystać może z Adornowskiego przykazania: „Esej myśli uskokami [...]”; „[...] musi on zawsze tak przylegać, aby zawsze móc się oderwać” [Adorno 1990: 92].

\section{Bibliografia}

Adorno Theodor W. (1990), Esej jako forma, w: tegoż, Sztuka i sztuki. Wybór esejów, przeł. Krystyna Krzemień-Ojak, wybór i wstęp Karol Sauerland, PIw, Warszawa, s. 79-99.

Atkins G. Douglas (2005), Tracing the Essay. Through Experience to Truth, The University of Georgia Press, Atens-London.

Barska Joanna (2008), La musique nes't pas représentable? Ekfraza muzyczna jako szczególny rodzaj komunikacji intersemiotycznej, w: Komunikacja przez sztukę, komunikacja przez język, red. Bartłomiej Bączkowski, Paweł Gałkowski, Zakład Teorii i Filozofii Komunikacji Uniwersytetu im. Adama Mickiewicza w Poznaniu, Poznań, s. 77-88. Bieńkowska Ewa (1976), Sztuka eseju, „Znak”, nr 1, s. 101-107. D’Agata (2012), [From „2003” in The Next American Essay], w: Essayists on the Essay. Montaigne to Our Time, red. Carl H. Klaus, Ned

Stuckey-French, University of Iowa Press, Iowa City, s. 169-170.

Głowala Wojciech (2014), Swego czasu, Atut, Wrocław.

Górny Tomasz (2017), Polifonia. Od muzyki do literatury, Universitas, Kraków.

Hawryszków Kama (2011), Felieton „umuzyczniony” Stefana

Kisielewskiego, w: Dysonanse. Twórczość Stefana Kisielewskiego (19111991), red. Andrzej Hejmej, Kama Hawryszków, Katarzyna CudzichBudniak, Wydawnictwo Uniwersytetu Jagiellońskiego, Kraków, s. 149-157.

Hejmej Andrzej (2002), Muzyczność dzieła literackiego, Wydawnictwo Uniwersytetu Wrocławskiego, Wrocław. 
Huxley Aldous (1960), Collected Essays, Chatto \& Windus, New York. Iwaszkiewicz Jarosław (2010), Chopin, wyd. 8, PwM, Kraków.

Kapchan Deborah (2017), Splash of Icarus. Theorizing the Sound Writing /

Writing Sound Theory, w: Theorizing Sound Writing, red. Deborah

Kapchan, Wesleyan University Press, Middeltwon, s. 1-22.

Kierzek-Trzeciak Paulina (2010), Ekfraza muzyczna, czyli o opisie muzyki raz jeszcze, w: Młodopolska synteza sztuki, red. Hanna Ratuszna, Radosław Sioma, Wydawnictwo Naukowe uMK, Toruń, s. 49-6o.

Lisak-Gębala Dobrawa (2016), Wizualne odskocznie. Wokót wspótczesnej polskiej eseistyki o malarstwie i fotografii, Universitas, Kraków.

Lukács György (1994), O istocie i formie eseju. List do Leo Poppera, przeł. Ryszard Turczyn, w: Pisma krytyczno-teoretyczne Georga Lukácsa. 1908-1932, wybór i wstęp Stefan Morawski, Instytut Kultury, Warszawa, s. 82-92.

Łukasiewicz Małgorzata (2011), Jak być artystą. Na przykładzie Thomasa Manna, Towarzystwo Więź, Warszawa.

Mann Tomasz (2008), Czarodziejska góra, przeł. Józef Kramsztyk, Jan Łukowski, Muza, Warszawa.

Markowski Michał Paweł (1999), Ekphrasis. Uwagi bibliograficzne $z$ dołączeniem krótkiego komentarza, „Pamiętnik Literacki”, z. 2, s. 229-236.

de Montaigne Michel (2004), Próby, przeł. Tadeusz Boy-Żeleński, Zielona Sowa, Kraków.

Pikulska Ilona (2008), Dwudziestowieczne biografie literackie Fryderyka Chopina, Katowice, [dostęp: 16 września 2020], https://tinyurl.com/22wudwv6, [praca doktorska].

Pociej Bohdan (2012), Polskość Chopina, wprowadzenie i red. Ewa Sławińska-Dahlig, NIFC, Warszawa.

Przybylski Ryszard (1995), Cień jaskótki. Esej o myślach Chopina, Znak, Kraków.

Sendyka Roma (2006), Nowoczesny esej. Studium historycznej świadomości gatunku, Universitas, Kraków.

Sendyka Roma (2009), Esej i ekfraza (Herbert - Bieńkowska - Bieńczyk), „Przetrzenie Teorii”, nr 11, s. 41-61.

Smolka Iwonai in. (2010), „Staroświecki meloman” - jubileusz Piotra

Wierzbickiego [rozmowa], „Tekstualia”, nr 3, s. 133-144.

Stefańczyk Tadeusz (2017), Styszeć więcej, „Twórczość”, nr 3, s. 110-116.

Tomkowski Jan (2017), Wstęp, w: Polski esej literacki. Antologia, red. Jan Tomkowski, Wrocław, s. v-cX.

Wierzbicki Piotr (1993), Życie z muzyka, pIw, Warszawa. 
Wierzbicki Piotr (1999), Chopin. Portret muzyczny, Krajowa Agencja

Wydawnicza, Warszawa.

Wierzbicki Piotr (2002), Mikrokosmos, Alfa, Warszawa.

Wierzbicki Piotr (2010a), Migotliwy ton. Esej o stylu Chopina, Sic!,

Warszawa.

Wierzbicki Piotr (2010b), Muzykalny kosmos, Świat Książki, Warszawa.

Wierzbicki Piotr (2014), Boski Bach, Sic!, Warszawa.

Wierzbicki Piotr (2015), Nieboski Chopin, Sic!, Warszawa.

Wierzbicki Piotr (2016), Jak słuchać muzyki, Towarzystwo Więź, Warszawa.

Zawadzki Andrzej (2001), Nowoczesna eseistyka filozoficzna $w$ piśmiennictwie polskim pierwszej połowy $\mathrm{xx}$ wieku, Universitas, Kraków.

\section{Dobrawa Lisak-Gębala}

\section{Chopinology in Piotr Wierzbicki's Essays}

Piotr Wierzbicki's deep interest in Chopin's music has been revealed in his volumes of essays published since 1993. What appears to make his music writings exceptional in comparison with other Polish essays dealing with Chopin's life and work is the prevailing concentration on particular pieces or even single performances chosen by famous pianists. Wierzbicki develops his project of extradisciplinary essayistic Chopinology that blends together the musicological knowledge, critical involvement, philosophical reflection and highly individual psychosomatic experience. Having stated a fundamental difficulty of 'translating' sounds into words, he tries to elaborate a 'musical' style and form for his writing, e.g. he includes ekphrases full of metaphors and synesthetic figures. This wide array of music-centred properties encourages readers to treat these essays as a starting point for coming up with the question of whether it is possible to differentiate a type of 'musical' essay.

Keywords: Piotr Wierzbicki; Frédéric Chopin; essay; musical ekphrasis; word-music relations; sound writing.

Dobrawa Lisak-Gębala - doktor, ur. w 1984 roku, ukończyła studia kulturoznawcze i polonistyczne na Uniwersytecie Wrocławskim. Autorka monografii Ultraliteratura (2014) i Wizualne odskocznie (2016), współredaktorka tomów Esej-sztuka-nauka (2011), Czytając Czapskiego (2015) oraz Centra-peryferie $w$ literaturze polskiej Xx $i$ XXI wieku (2015). Artykuły naukowe publikowała 
m.in. w „Pamiętniku Literackim”, „Zagadnieniach Rodzajów Literackich”, „Przestrzeniach Teorii”, „Autobiografii”, „Czytaniu Literatury” i „Res Facta Nova”. Zajmuje się historią literatury polskiej xx i XxI wieku, teorią eseju oraz badaniami nad intermedialnością ( $w$ tym z kręgu sound studies, obecnie $w$ ramach projektu na temat poetyckiej tanatosoniki). Adres e-mail: dobrawa. lisak-gebala@uwr.edu.pl. 